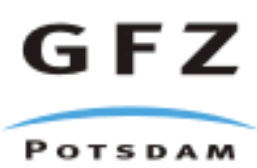

Originally published as:

Kristen, I., Fuhrmann, A., Thorpe, J., Röhl, U., Wilkes, H., Oberhänsli, H. (2007):

Hydrological changes in southern Africa over the last $200 \mathrm{Ka}$ as recorded in lake sediments from the Tswaing impact crater. - South African Journal of Geology, 110, 2-3, 311-326,

DOI: 10.2113/gssajg.110.2-3.311. 


\title{
Hydrological changes in southern Africa over the last 200 kyr as recorded in lake sediments from the Tswaing impact crater
}

\author{
I. Kristen \\ GeoForschungsZentrum Potsdam, Telegrafenberg, D-14473 Potsdam, Germany, kristen@gfz-potsdam.de \\ A. Fuhrmann \\ GeoForschungsZentrum Potsdam, Telegrafenberg, D-14473 Potsdam, Germany \\ Present address: Saudi Aramco, Dhahran 31311, Saudi Arabia, andreas.fuhrmann@aramco.com \\ J. Thorpe \\ formerly at Department of Geography, University College London, 26 Bedford Way, London WC1H 0AP, Great \\ Britain, jo_thorpe@yahoo.com \\ U. Röhl \\ Center for Marine Environmental Sciences (MARUM), Universität Bremen, Leobener Strasse, 28359 Bremen, \\ Germany, uroehl@marum.de \\ H. Wilkes \\ GeoForschungsZentrum Potsdam, Telegrafenberg, D-14473 Potsdam, Germany, wilkes@gfz-potsdam.de \\ and \\ H. Oberhänsli \\ GeoForschungsZentrum Potsdam, Telegrafenberg, D-14473 Potsdam, Germany, oberh@gfz-potsdam.de
}

Short working title: Hydrological changes recorded in sediments from Lake Tswaing (South Africa)

\begin{abstract}

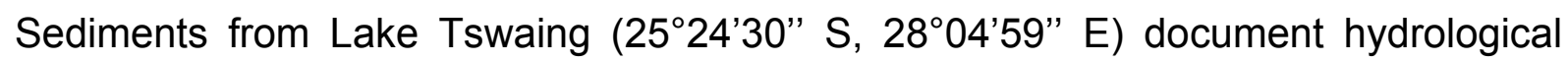
changes in southern Africa over the last 200 kyr. Using high-resolution XRFscanning, basic geochemistry (TIC, TOC, TN), organic petrology and Rock-Eval pyrolysis, we identify intervals of decreased carbonate precipitation, increased detrital input, decreased salinity and decreased autochthonous (algal and bacterial) organic matter content that represent periods of less stable water column stratification and increased rainfall. Between 200 and $80 \mathrm{kyr}$ BP, these intervals appear to be contemporaneous with local summer insolation maxima, indicating a strong influence of precessional variability $(\sim 23 \mathrm{kyr})$ on African subtropical climate. This influence
\end{abstract}


weakens during the last glacial period ( 80-10 kyr BP), when humid intervals at 73$68 \mathrm{kyr}, 54-50 \mathrm{kyr}, 37-35 \mathrm{kyr}$ and 15-10 kyr BP are largely out of phase with insolation changes, and presumably reflect southward displacement of the ITCZ (Inter Tropical Convergence Zone) and/or changes in ocean circulation.

\section{Introduction}

In order to understand natural climate variability it is important to have long, continuous and well dated climate records from the continents and oceans of both hemispheres, but such records are rare in the southern hemisphere, and especially in southern Africa.

In the last decade, deep coring in Lake Malawi ( $L$ in Fig. 1 ) has provided records of lake level-change, diatom composition and temperature over the last 25 to $50 \mathrm{kyr}$ (Finney et al., 1996; Johnson et al., 2002; Powers et al., 2005). Finney et al. (1996) found lake levels 200 to $300 \mathrm{~m}$ lower than today for most of the period $\sim 40$ to $28 \mathrm{kyr}$ BP and a lake 100 to $150 \mathrm{~m}$ shallower than today for the early Holocene. Johnson et al. (2002) and Powers et al. (2005) identified changes in atmospheric circulation and cooler temperatures during the Younger Dryas and the 8.2 kyr-event, indicating a close connection with northern hemisphere climate. Records from stalagmites (e.g. Holmgren et al., 2003; Lee-Thorp et al., 2001; Talma and Vogel, 1992) provide precisely dated, high-resolution records of climate variability in South Africa during the Holocene and the late glacial (last $\sim 30 \mathrm{kyr}$ ). According to these studies, temperatures were 5 to $7^{\circ} \mathrm{C}$ lower than today during the Last Glacial Maximum, then increased in a two step warming at $\sim 17$ and $13.5 \mathrm{kyr}$ BP. A similar pattern of warming was found by Gasse (2000) and Partridge et al. (1999) in southern Africa. Records of humidity changes in South Africa are rarer and less clear (Partridge et al., 1999). The 
available speleothem records (Holmgren et al., 1995; Holmgren et al., 2003; Talma and Vogel, 1992) contain hiatuses and do not cover complete glacial/interglacial cycles.

The longest and most continuous record of precipitation in South Africa is the sedimentary record from the crater lake Tswaing (formerly "Pretoria Saltpan") (Partridge et al. 1993, Partridge et al. 1997), which covers at least two glacial/interglacial cycles ( 200-2 kyr BP). The multidisciplinary study edited by Partridge (1999) gives a general overview of the origin, geology, sedimentology and limnology of the crater lake. A major finding of this study is the precessional (changes in earth's orbital configuration with $\sim 23,000$ year periodicity) control over the mineralogical composition and grain size distribution of the sediments over the last 200 kyr, which weakens during the last glacial period (Partridge, 1999). However, some questions remain about the extent of changes in lake level and the ecosystems over the period of the record, because both pollen and diatoms are absent from parts of the core, and yielded contradictory results in other sections (Scott, 1999; Metcalfe, 1999). Here we aim to provide further insights into changes in the ecosystems in and around the lake on glacial/interglacial time scales. For this purpose, we use organic petrology and Rock-Eval pyrolysis to characterise the composition of the organic matter (OM) in the lake sediments. With this approach, which has been successfully applied to European maar lakes (Fuhrmann et al., 2004) and the North American Great Lakes (Meyers, 2003), we can differentiate OM originating from different sources (Meyers and Lallier-Vergès, 1999). We interpret these data in the light of high-resolution records of the total inorganic carbon (TIC), total organic carbon (TOC) and total nitrogen (TN) content of the sediments of the complete profile and records of element distributions obtained by XRF scanning from the upper $30 \mathrm{~m}$ of the core. Using these data, we attempt to better characterise processes occurring within and 
around the lake over the period covered by the core and to provide a record of precipitation changes in southern Africa over the past $200 \mathrm{kyr}$.

\section{Geographic, geological and climatological settings}

The $1.13 \mathrm{~km}$-wide crater Tswaing is located approximately $40 \mathrm{~km}$ northwest of Pretoria at an altitude of $1045 \mathrm{~m}$ asl. The crater was fromed by a meteorite impact, which has been dated at $220 \pm 52$ kyr BP using fission-track dating (Reimold et al., 1992). The crater is situated in the $\sim 2 \mathrm{Ga}$ old Nebo Granite, the main granite type of the Bushveld complex (Brandt and Reimold, 1999). Since its formation, the crater has filled with material eroded from its walls and with autochthonous lacustrine sediments (Partridge et al. 1993). This infilling appears to have been at least partly responsible for a gradual shallowing of the waterbody documented in the mineralogical composition of the sediments (Bühmann and Elsenbroek, 1999). The crater walls reach $119 \mathrm{~m}$ above the crater floor and $60 \mathrm{~m}$ above the adjacent surface. They create an enclosed basin with no surface outflow and a central lake. This lake is today 2 to 3 m deep, alkaline, with a pH value around 10, and hypersaline (up to 250$300 \%$ in bottom waters). Its surface area shrinks by $20-25 \%$ during winter times, causing an average lake level fall of $20 \mathrm{~cm}$ below summer high stands (based on a monitoring phase of 28 months; Ashton and Schoeman, 1983). The high salinity causes the water body to be constantly stratified and thus mostly anoxic below $50 \mathrm{~cm}$ water depth (Ashton, 1999). The high salinity and alkalinity are also responsible for the dominance of bacteria, blue-green algae and protists in the lake water body. A few diatom species inhabit areas where fresh groundwater seeps out of the crater wall. This groundwater inflow, together with rainfall, represents the only natural source of fresh water entering Lake Tswaing. Artesian boreholes that reach down to 
sandy aquifers below the lacustrine facies provide additional inflow since the 1970 s (Ashton and Schoeman, 1983; Partridge et al., 1993). The total annual rainfall in this region varies between 400 and $750 \mathrm{~mm}$ per year. The rainfall distribution is highly seasonal, with a maximum during the austral summer months (October to April) when the ITCZ reaches its southernmost position (Fig. 2). The ITCZ marks the region of the thermal equator where the tropical easterly flows converge and create convective rainfall (Preston-Whyte and Tyson, 1988). Annual precipitation is exceeded by an average annual evaporation of $2,375 \mathrm{~mm}$. Monthly mean maximum and minimum air temperatures in the region range from $14.2^{\circ} \mathrm{C}$ to $35.2^{\circ} \mathrm{C}$ and $3.6^{\circ} \mathrm{C}$ to $15.6^{\circ} \mathrm{C}$, respectively (Ashton, 1999). The vegetation around the crater is classified as mixedand sourish-mixed bushveld assemblages and consists of grassland mixed with deciduous trees and shrubs dominated by Acacia and Combretum species (Acocks, 1953).

\section{Material and methods}

During a coring campaign in 2001/2002, approximately $90 \mathrm{~m}$ of sediments were recovered from the lake using Shelby tube drilling for the upper $33 \mathrm{~m}$ and wireline rotary core drilling with a triple-tube core barrel for the lower section. The sediments are composed of granitic sands in the lowermost few meters, followed by partly laminated lake sediments (Fig. 3). The lake sediments consist of carbonatedominated marls below $\sim 35 \mathrm{~m}$ depth, and halite and fluorite-bearing organic-rich muds in the upper $35 \mathrm{~m}$ (Bühmann and Elsenbroek, 1999). Mass flows up to $1.5 \mathrm{~m}$ thick are intercalated with lacustrine sediments, particularly between depths of 35 and $50 \mathrm{~m}$ and 70 and $77 \mathrm{~m}$. These deposits are primarily composed of sand and gravels derived from the crater walls. To create the final composite profile, which is 
$78 \mathrm{~m}$ long (shown in Fig. 4, 5, 6, 9 and 10, and referred to in the text if not quoted otherwise), mass flows were excluded, as they are considered abrupt events that disrupt the continuous sequence of sediments (Partridge et al., 1997; Garcin et al., $2006 \mathrm{~b}$ and references therein).

A total of 217 samples were collected at between 30 and $50 \mathrm{~cm}$ resolution and analysed for total carbon (TC), total inorganic carbon (TIC), total organic carbon (TOC) and total nitrogen (TN) content. TIC was determined coulometrically after release of carbon dioxide by reaction with hot phosphoric acid (1:1) (device: Coulomat 702, Ströhlein). The TIC concentrations represent mean values of double measurements. The relative difference between the single measurements was typically below $1 \%$, but for TIC contents below $0.1 \%$ the difference occasionally reached $10 \%$.

TC and TN were analysed using the EuroVector EA3000 Elemental analyzer. Approximately $10 \mathrm{mg}$ of sediment was wrapped in tin and combusted under oxygen flow at $>1000{ }^{\circ} \mathrm{C}$. After combustion, $\mathrm{CO}_{2}$ and $\mathrm{N}_{2}$ were separated using a $\mathrm{GC}$ column and detected using thermal conductivity. The precision for TC was $<1 \%$ and for TN $<5 \%$. TOC was determined by calculating the difference between TC and TIC.

Twenty-one samples were collected to characterise the organic material preserved in the sediments using Rock-Eval pyrolysis and maceral analysis (Table 2). Maceral analysis was carried out by qualitative microscopic inspection of polished blocks using a Zeiss Axioplan microscope in reflected white light and with blue light excitation at $365 \mathrm{~nm}$. Total organic carbon (TOC), hydrogen index ( $\mathrm{HI}$ ) and $\mathrm{T}_{\max }$ (definition later in this paragraph) were determined using a Rock-Eval 6 instrument following the procedures described by Espitalié et al. $(1977 ; 1985)$ and Lafargue et al. (1998). The TOC values from Rock-Eval pyrolysis are very similar to those 
calculated from the difference between TC and TIC, confirming the validity of the latter approach. The $\mathrm{HI}$ corresponds to the yield of volatile organic compounds released by pyrolysis of the macromolecular OM in the sediments and is controlled by the amount of hydrogen in the organic material (kerogen), which is generally higher for algal and bacterial matter than for vascular plants (Meyers and LallierVergès, 1999). $T_{\max }$ is the temperature at which the greatest amount of volatile organic compounds is released during continuous heating from $\sim 200$ to $850{ }^{\circ} \mathrm{C}$. This parameter describes the thermal evolution of organic matter in the sediment. It can be correlated with vitrinite reflectance (e.g. Tissot et al., 1987), which is the most commonly used parameter to describe the changes of microscopic organic constituents during maturation. It is measured using a microscope with incident light and increases with increasing maturity (Taylor et al., 1998). The $\mathrm{HI}$ versus $\mathrm{T}_{\max }$ diagram can be used to evaluate thermal maturity and to classify the kerogen type of OM in the sediments.

The core sections of the upper $31 \mathrm{~m}$ were scanned for selected elements at $3 \mathrm{~cm}$ resolution using the X-ray fluorescence Core Scanner II at MARUM of the University of Bremen (Germany). A special emphasis was placed on the upper $31 \mathrm{~m}$ of the sediments because it is during this time interval $(\sim 80 \mathrm{kyr})$ that previous investigations indicate a change in the controls on climate at the site (Partridge, 2002). The XRF core scanner was used to measure major elements (e.g., Al, Si, S, K, Ca, Ti, Cl, and Fe) on split sediment cores as described in Richter et al. (2006), Röhl and Abrams (2000) and Tjallingii et al. (2007). This is a widely accepted, semi-quantitative, nondestructive core logging method that provides records of changing element intensities expressed in "total counts", reflecting the geochemical composition of the sediments. We excluded intervals rich in mass flow material, evaporitic crusts and concretions 
because the sediment surface was too rough to perform the scanning in these intervals.

\section{Chronostratigraphy}

The age model for the upper $25 \mathrm{~m}$ of the profile is based on nine new radiocarbon ages (Tab. 1 and Fig. 4) determined at the Poznan Radiocarbon Laboratory. Three of the dates are on microscopic charcoal fragments, and the others are on bulk OM. A reservoir correction of 1,150 years (the mean age offset of 11 samples from recent lake sediments; Partridge et al., 1997) was applied to the two youngest ages on bulk OM . This correction was applied to these samples because they were taken from intervals where autochthonous material (bacterial and algal) dominates the organic fraction of the sediments (see section 5.3). The reservoir effect is assumed to be constant for the last 5,000 yr BP. Beyond this time interval we did not adjust the measured ages, as these samples were obtained from TOC poor intervals where maceral investigation reveals that the OM present is predominantly of terrestrial origin.

The ages show a regular increase with depth, with the exception of one bulk sample (Fig. 4). This sample was taken immediately below the charcoal sample from $14.8 \mathrm{~m}$ depth, but has a ${ }^{14} \mathrm{C}$ age 10,000 years older; an offset that is probably due to contamination with old OM. This sample is therefore excluded from the age model. For samples younger than $24,000{ }^{14} \mathrm{C}$ years, the ages were calibrated using Calib 5.0.2 after McCormac et al. (2004) and Reimer et al. (2004) (calibration curve SHCal04 for samples younger than 11 cal kyr BP and IntCal04 for samples older than 11 cal kyr BP). Ages older than $24,000{ }^{14} \mathrm{C}$ years were calibrated using CalPal (calibration curve CalPal2005_SFCP). 
The chronology confirms the previously-published age model based on seven radiocarbon ages from bulk organic material, which was established for a core retrieved in 1988 (Partridge et al., 1993) (Fig. 4).

Below the radiocarbon-dated section, the age model rests on the fission-track date of $220 \pm 52$ kyr BP from impact glass (Koeberl et al., 1999). An attempt to gain a betterconstrained age for this material using ${ }^{40} \mathrm{Ar} /{ }^{39} \mathrm{Ar}$ dating did not provide reliable results due to inherited ${ }^{40} \mathrm{Ar}$ (Jourdan et al., 2007). Furthermore, tests to assess the suitability of quartz grains from the sediments for OSL dating failed (Stephan Woodborne, pers. com. 2006). We therefore constructed an age model for the sediments below 20 m depth using the same procedure as Partridge et al. (1997). This involved tuning our TIC record to the record of January insolation at $30^{\circ} \mathrm{S}$. This approach seems appropriate due to the similarities between the reconstructed palaeo-rainfall record from Partidge et al. (1997), our TIC record, and the record of January insolation. The tuning process results in a maximum deviation of 5,000 years between the tuned age model and an age model constructed by linear interpolation between the last radiocarbon age $(48,440$ cal. yr BP) and a basal age of $200 \mathrm{kyr}$ BP (allowing $\sim 20,000$ years for the deposition of $\sim 15 \mathrm{~m}$ of terrigenous sands and gravels that underlay the lacustrine sequence; Partridge et al. 1999) (Fig. 4).

\section{Results and discussion}

\section{$\underline{5.1 \text { Basic geochemistry (TIC, TOC, TN) of the complete profile }}$}

The records of TIC (range: 0 to $10 \%)$, TOC (0 to $8 \%$ ) and TN (0 to $0.4 \%)$ are displayed in Figure 5. All datasets show considerable variability. The amplitude of variations in TIC is greatest below $35 \mathrm{~m}$ ( 93 kyr BP according to the age/depth 
relationship presented in Tab. 1 and Fig. 4), while the amplitude of variations in TOC is greatest above $35 \mathrm{~m}$. This change correlates with the change in the prevailing lithologies (carbonaceous marls vs organic-rich muds; see Fig. 3) and presumably documents a shift in the lake system. Below $35 \mathrm{~m}$, higher TIC content appears to reflect stronger evaporation (Partridge et a. 1997), while above $35 \mathrm{~m}$, increased evaporation appears to lead to increased quantities of halite (see section 5.2). This change may be a result of brine evolution (Eugster and Hardie, 1978), but it can also be related to the rapid shallowing of the lake by prominent mass flow deposition, and its greater sensitivity to changes in the precipitation/evaporation ratio after these events. The record of TN shows similar fluctuations to the record of TOC. The TOC/TN ratios are, on average, lower above $30 \mathrm{~m}$ depth (19.8 above $30 \mathrm{~m}$ compared to 28.4 below $30 \mathrm{~m}$ ).

\section{$\underline{5.2 \text { Element geochemistry (XRF core scanning) }}$}

The XRF scans of our studied cores reveal changes in the importance of selected elements that result from varying detrital input and/or authigenic processes. Element intensities of silica $(\mathrm{Si})$, potassium $(\mathrm{K})$, titanium $(\mathrm{Ti})$, iron $(\mathrm{Fe})$, aluminium $(\mathrm{Al})$, sulphur (S), calcium ( $\mathrm{Ca})$ and chlorine $(\mathrm{Cl})$ in the upper $31 \mathrm{~m}(\sim 84 \mathrm{kyr} \mathrm{BP})$ of organic-rich muds are compared to the mineralogical data of Bühmann and Elsenbroek (1999) (Figure 6). $\mathrm{Si}, \mathrm{K}, \mathrm{Ti}$ and Fe show similar trends, increasing from 4 to $5.5 \mathrm{~m}, 13 \mathrm{~m}, 18$ to $20 \mathrm{~m}$ and from 24.5 to $27 \mathrm{~m}(\sim 10-15,35-37,50-54$ and 68-73 kyr BP). Mineralogical and chemical data of the lake sediments revealed that quartz, feldspars (microcline $\quad\left(\mathrm{KAISi}_{3} \mathrm{O}_{8}\right)$ and plagioclase $\left.\quad\left((\mathrm{Na}, \mathrm{Ca})(\mathrm{Si}, \mathrm{Al})_{4} \mathrm{O}_{8}\right)\right)$, smectites $\left((\mathrm{Na}, \mathrm{Ca}) \mathrm{Al}_{4}(\mathrm{Si}, \mathrm{Al})_{8} \mathrm{O}_{20}(\mathrm{OH})_{4} \cdot 2\left(\mathrm{H}_{2} \mathrm{O}\right)\right)$ and illite $\left(\mathrm{KAl}_{2}\left[(\mathrm{OH})_{2} \mathrm{AlSi}_{3} \mathrm{O}_{10}\right]\right)$ are the major detrital minerals (Bühmann and Elsenbroek, 1999). For the studied upper $31 \mathrm{~m}$ of the record/section, the relative amounts of quartz, feldspars and plagioclase co-vary with 
the intensities of $\mathrm{Si}, \mathrm{K}, \mathrm{Ti}$ and $\mathrm{Fe}$. We therefore infer that these elements reflect detrital, minerogenic input from the shore and the crater wall, which derives from the granitic bedrock that consists of $37-63 \%$ quartz, $10-27 \%$ microcline, $18-54 \%$ plagioclase and $<5 \%$ mica (Bühmann and Elsenbroek, 1999). The Al values do not co-vary with the other elements. Similar to the relative abundance of smectites, Al displays a rather smooth trend, which is probably the result of a balance between aeolian inputs and sheetwash, whereas $\mathrm{K}, \mathrm{Si}$, Ti and Fe derive only from sheetwash. The amount of $\mathrm{Cl}$ reflects the abundance of halite $(\mathrm{NaCl})$, which is a major component of the lake sediments in the uppermost $31 \mathrm{~m}$ of the cored sequence (Bühmann and Elsenbroek, 1999) and is indicative of saline conditions in the lake. Today it makes up $66 \%$ of the salt deposits that are deposited around the lake during the dry season (Bühmann and Elsenbroek, 1999). Contrary to Partridge et al. (1993), who considered the halite in the sediments to be primarily a secondary precipitate from pore water, we interpret it as in-situ product forming in the water column or at least near the sediment surface. This interpretation is based on the anti-correlation of $\mathrm{Cl}$ to the detrital elements and its correlation with the TOC content of the sediments (see section 5.3). Sulphur could be related to the occurrence of gypsum, diagenetic components like pyrite or in OM. In some intervals, the abundance of S co-varies with the intensity of Fe, which may reflect the presence of iron sulfides produced by diagenetic processes, but neither pyrite nor gypsum are major components of the sediments (Bühmann and Elsenbroek, 1999). Calcium, like S, does not show a clear correlation with other elements. This element is present in plagioclase and smectite, which can occasionally form up to $30 \%$ of the minerogenic fraction, but is also present in autochthonous calcite. The fact that $\mathrm{Ca}$ occurs in both detrital and authigenic minerals may explain the low amplitude of variations in the abundance of this element, as the relative abundance of detrital and authigenic minerals are anti- 
correlated. This effect is probably especially important in the upper $\sim 23 \mathrm{~m}$ of the profile where calcite comprises, on average, $7 \%$ of the minerogenic fraction compared to $36 \%$ between 23 and 78 m depth (Bühmann and Elsenbroek, 1999).

\subsection{Organic petrology and Rock-Eval pyrolysis}

Organic petrology using microscopic methods is a useful means of characterising OM in lake sediments in order to reconstruct palaeoclimatic variations (e.g. Fuhrmann et al., 2003; Patience et al., 1996; Sifeddine et al., 1996). Particulate autochthonous OM can be differentiated from ligno-cellulosic allochthonous OM due to its different morphology and fluorescence characteristics. For example, algal OM appears light green, yellowish or orange under blue light excitation, whereas fresh terrestrial plant material appears black or dark brown and often has cellular or fibrous structures (Taylor et al., 1998). High reflectance terrigenous particulate OM (which appears steel-grey under normal white light, Fig. $7 \mathrm{c}$ and d) represents input of eroded geologically older OM or oxidised fragments (Fuhrmann et al., 2004). In the investigated profile, samples high in TOC contain frequent layers of autochthonous material in the form of filamentous algae or cyanobacteria (F, Fig. 7 a and b), as well as abundant colonies of the colonial green alga Botryococcus braunii (B, Fig. 7 a). In the deepest $15 \mathrm{~m}$ of the core, unknown filamentous algae dominate the autochthonous organic fraction. Pollen grains are rare, but other terrestrial plant material is frequently present in organic-rich samples. It forms dark layers where sediments are laminated (T, Fig. $7 \mathrm{~b}$ ), or is present as single particles with fibrous and cellular structures where sediments are homogenous (Fig. 7 e). A considerable proportion of these particles seem to be relatively highly oxidised (Fig. 7 c, d). Samples with TOC $<0.5 \%$ lack any recognisable autochthonous organic 
components. Most of the OM in these samples consists of small, oxidised terrigenous particles (Fig. 7 c).

Rock-Eval pyrolysis data show that the sediments from Lake Tswaing can be divided into 3 groups according to their $\mathrm{HI}$ and $\mathrm{T}_{\max }$ values (group A, B, C in Fig. 8, Tab. 2). Group A has $\mathrm{HI}$ values higher than $300 \mathrm{mg} \mathrm{HC/g}$ TOC and $\mathrm{T}_{\max }$ values higher than $400^{\circ} \mathrm{C}$. Group B has $\mathrm{HI}$ values lower than $300 \mathrm{mg} \mathrm{HC} / \mathrm{g} \mathrm{TOC}$ and $\mathrm{T}_{\max }$ values higher than $400^{\circ} \mathrm{C}$, while the $\mathrm{HI}$ values of group $\mathrm{C}$ are lower than $300 \mathrm{mg} \mathrm{HC} / \mathrm{g}$ and the $\mathrm{T}_{\max }$ values are lower than $380^{\circ} \mathrm{C}$. The latter are found in the interval between 35 and 55 m ( 40-60 m uncorrected depth in Fig. 3, $\sim 93-145$ kyr BP). For samples above and below this interval, $\mathrm{HI}$ and TOC co-vary and $\mathrm{T}_{\max }$ remains stable at around $430^{\circ} \mathrm{C}$ (Fig. 8, Tab. 2). As expected for relatively young sediments like those from Lake Tswaing, thermal maturity as assessed by $T_{\max }$ is low, with vitrinite reflectance $\left(R_{r}\right)$ mainly below $0.5 \%$ (Fig. 8, Taylor et al., 1998). The distribution within the $\mathrm{HI}^{-\mathrm{T}_{\max }}$ diagram (Fig. 8) can be used to identify the kerogen type (Types I, II, III, indicated by dashed lines in Fig. 8), and thus indicates the origin of the OM (Meyers and LallierVergès, 1999). Type I OM, which is especially rich in hydrogen, predominantly derives from microbial biomass or the waxy coatings of terrestrial plants. Type II OM, which is moderately enriched in hydrogen, typically derives from autochthonous sources, particularly algae. Higher plant debris is primarily Type III OM, which is poor in hydrogen. Samples from group B can be classified as samples containing Type III OM. They are characterised by TOC contents $<1 \%$. Samples from group A have TOC values $>1 \%$ and contain predominantly Type II OM. Generally lower TOC/TN ratios (Fig. 5) support the results from Rock-Eval pyrolysis that, particularly in the upper $30 \mathrm{~m}$, autochthonous OM is the main component of TOC (Meyers, 2003). The high TOC content of the samples, combined with the presence of well-preserved land 
plant debris and the laminated nature of the sediments in some sections, indicate that conditions were anoxic in the hypolimnion and in the sediments of the lake.

The $\mathrm{OM}$ in samples from group $\mathrm{C}$, which have very low $\mathrm{T}_{\max }$ values, can not be classified according to this scheme (Samples 12, 14, 15, 16 in Tab. 2 and Fig. 8). Scott (1999) reported that the interval between 30 and $60 \mathrm{~m}$ is barren of pollen and suggested that this was due to oxidation of OM during deposition in a shallow lake environment or during subaerial exposure of the sediments during arid events at the top of this section. Diatom investigations indicate, however, that the lake water was relatively fresh (conductivity generally less than $1000 \mu \mathrm{Scm}^{-1}$ ) and moderately alkaline $(\mathrm{pH} 7.5-8.5)$ with a trend towards more alkaline conditions at the top of the section $(\sim 35 \mathrm{~m})$ (Metcalfe, 1999). Between $\sim 40$ and $50 \mathrm{~m}$, the diatom assemblage composition indicates that conditions were well mixed. Thin sections indicate that there is inter-annual or seasonal lamination between $\sim 50$ and $43 \mathrm{~m}(\sim 58-50 \mathrm{~m}$ in Fig. 3), with diatom-rich horizons alternating with carbonaceous and clastic-rich horizons (Fig. 7 f). This lamination suggests that benthic organisms were absent, possibly due to anoxic conditions in the hypolimnion, but that there was enough seasonal variation in the epilimnion to allow diatom blooms, calcite precipitation, and sedimentation from sheetwash. Bioturbational structures occur at $\sim 35 \mathrm{~m}$ depth $(\sim 40 \mathrm{~m}$ in Fig. 3), indicating that conditions were sufficiently oxygenated to support benthic organisms. In summary, results from the study of diatom assemblages and sedimentology indicate the presence of a freshwater lake that was deep enough to sustain a well mixed epilimnion and an anoxic hypolimnion. Towards the top of the section, at $\sim 35$ $\mathrm{m}$, the lake appears to have become shallower, allowing complete mixing of the water body. The reason for the lack of OM remains uncertain, but is probably due to oxidation of OM in either the epilimnion or in the sediments after deposition. 
Above $\sim 35 \mathrm{~m}$ depth, the combination of results from organic and inorganic geochemistry and XRF shows that TOC content is generally low and predominantly composed of allochthonous material when $\mathrm{Cl}$ intensities are low and the intensities of detrital elements (K, Fe, $\mathrm{Ti}$ and $\mathrm{Si})$ are high, indicating increased runoff. We interpret these observations as an indication of increasingly oxic conditions in the lake water column due to less stable lake stratification related to increased freshwater inflow which reduces salinity. These conditions are less favourable for the preservation of OM but might also be less favourable for the bacterial and algal community and thereby lead to a decrease in organic productivity. When TOC is high (>4 \%), autochthonous bacterial and algal production is increased and organic remains are frequently preserved (Figs. 5, 7, 8) along with terrestrial plant material. Chlorine intensities are relatively high during these periods, indicating a more saline environment with a stratified lake and anoxic conditions in the hypolimnion.

\section{$\underline{5.4 \text { Paleoclimatic interpretation }}$}

The record of grain size distribution (Partridge, 1999) along with sediment (Bühmann and Elsenbroek, 1999), diatom assemblage (Metcalfe, 1999) and pollen (Scott, 1999) composition from Tswaing is for the moment the best available record. These data indicate that insolation variability influenced climate in the low latitudes of the southern hemisphere between $\sim 200$ and $80 \mathrm{kyr}$ BP. The new records presented in this study confirm this finding (as far as is possible, given the limitations of the age model). Although the uncertainties in the chronology of the sedimentary sequence from Lake Tswaing for the period $>48,440 \mathrm{yr}$ BP means that caution is necessary when discussing the timing of palaeoclimatic changes, we will attempt to evaluate our records in the context of other records of palaeoclimatic changes from the subtropics. 
For the time period between $\sim 200$ and $80 \mathrm{kyr}$ BP, lower amounts of carbonate in the sediments (which we suggest reflects higher summer rainfall) appear to be related to higher summer insolation values at $30^{\circ} \mathrm{S}$, which are, in turn, related to precessional maxima (Fig. 9 a and b). Analogous to seasonal changes today, increased solar radiation during the southern hemisphere summer season may have increased the intensity of convection associated with the ITCZ in the southern hemisphere, which may have resulted in more intense and/or longer periods of summer rainfall in this area (Tyson, 1999). Other records from southern Africa support this interpretation. Brook et al. (1997) presented speleothem records from several caves in Namibia and south-eastern Africa (Fig. 1). The records from the caves in south-eastern Africa indicate that conditions were humid 133-131, 111-103, 93-83 and 77-69 kyr BP; periods that correspond reasonably well with intervals of lower TIC content in the sediments of Lake Tswaing, indicating that the climate was relatively wet (Fig. 9 a, b). The speleothems from caves in northern Namibia record increased aridity 105-100 and $\sim 60$ kyr BP, with maximum aridity between 130 and 112 kyr BP (Fig. 9 c). The highest TIC values, which indicate high levels of evaporation, are recorded in the sediments from Lake Tswaing at this time ( 46-49 m depth) (Figs. 9 a, 5). Insolation variability also has a strong influence on local climate in the subtropics of South America, where stalagmites record increases in tropical rainfall during southern hemisphere insolation maxima over the past 210 and 120 kyr (Wang et al., 2004; Cruz et al., 2005). For the northern hemisphere subtropics, precessional influence on monsoonal climates in Africa and Asia is well established (e.g. Clemens et al., 1991; deMenocal et al., 2000; Prell and Campo, 1986; Wang et al., 2001). It therefore appears that between 200 and $80 \mathrm{kyr}$ BP changes in precessional parameters affected aridity (as reflected by the amount of carbonate in the sediments) and 
precipitation (as reflected by the amount of detritus) in southern Africa, as originally proposed by Partridge (1999).

After $80 \mathrm{kyr}$ BP, the reconstructed rainfall curve, which was based on grain size and the amount of carbonate in the sediments (Partridge (1999); Fig. 9 b), shows lower amplitude changes, in common with the insolation values, although the two records diverge after $60 \mathrm{kyr} \mathrm{BP}$. The rainfall record peaks before the corresponding insolation maximum at $\sim 47 \mathrm{kyr} \mathrm{BP}$ is reached, and it is relatively high $\sim 30 \mathrm{kyr} \mathrm{BP}$, when austral summer insolation is at a minimum. Furthermore, it exhibits a broad minimum from the Last Glacial Maximum until the middle Holocene ( 27-5 kyr BP). The latter finding is not corroborated by the XRF-element scans (Figs. 6, 9) presented in this study, or by mineralogical investigations (Bühmann and Elsenbroek, 1999). These lines of evidence indicate that detrital input from the crater walls due to higher rainfall increased at $73-68,54-50,37-35$ and 15-10 kyr BP. Studies based on records of dune activity and on lake sediments in the Kalahari also indicate that conditions were relatively humid during these intervals (left frame in Fig. 1 and Fig. 9 d) (Munyikwa, 2005; Thomas et al., 2003; Thomas and Shaw, 2002; O'Connor and Thomas, 1999; Stokes et al., 1998; Stokes et al., 1997). According to these studies, dunes formed between 36 and $28 \mathrm{kyr} \mathrm{BP}$, indicating that conditions were relatively arid at this time. This is the interval when $\mathrm{Cl}$ intensities are highest in the sediments from Tswaing, indicating that this was the most arid period of the last $80 \mathrm{kyr}$ at the site (Figs. 6 and 9). Arid periods also occurred $\sim 62-58 \mathrm{kyr} \mathrm{BP}, 50-38 \mathrm{kyr} \mathrm{BP}$, and 28-18 kyr BP. Sediments from Lake Tsodilo (Thomas et al., 2003; K in Fig. 1) document lacustrine conditions 40-32 and 18-11 kyr BP, while the lake was dry 32-18 kyr BP. Both the lacustrine intervals correspond with humid phases at Lake Tswaing. In southern Tanzania, recent magnetic susceptibility and pollen data (Garcin et al., 2006b; Garcin et al., 2006a) (G in Fig. 1) indicate relatively wet conditions 23-11 kyr BP and 
relatively dry conditions 45-23 kyr BP. At Alexandersfontein, Butzer et al. (1973) (A in Fig. 1) reported that lake levels increased during Termination I, at approximately 16 kyr BP. In caves in south-eastern Africa, Brook et al. (1997) (right frame in Fig. 1) identified humid periods with speleothem growth at $~ 50-43,36-35, \sim 23-19$ and 14-10 kyr BP (Fig. 9 c) and Pickering et al. (in press) (C in Fig. 1) dated periods of glacial flowstone growth to 56-42 and 16-10 kyr BP. High resolution stable isotope records from speleothems in Makapansgat Valley, which have good age control for the last 25 kyr BP (Holmgren et al., 2003; M in Fig. 1, Fig. 10 c, d) and the pollen record from Wonderkrater Spring (Scott and Holmgren, 2003; W in Fig. 1 and Fig. 10 f, g) indicate that conditions were dry and relatively cool 23-22 and 18-17 kyr BP in line with the records from Tswaing. After $\sim 13 \mathrm{kyr}$ BP the Makapansgat record indicates increasingly humid conditions, but a hiatus interrupts the record between 12.5 and 10 kyr BP.

During the early Holocene (10-7 kyr BP), all available southern African archives indicate warm and dry conditions, with peak aridity around $8 \mathrm{kyr}$ BP. During the middle and late Holocene, most of the records indicate gradually more humid conditions (Figs. 9 and 10). This trend contrasts with that observed in the northern hemisphere subtropics of Africa (e.g. deMenocal et al., 2000; Gasse, 2000; Kuper and Kropelin, 2006), where conditions appear to have been wet during the early Holocene, with a gradual reduction in rainfall during the middle and late Holocene. These changes are thought to be related to changes in northern hemisphere insolation, which appears to have influenced local climate after Termination I (Gasse, 2000; Holmgren et al., 2003 and references therein). Lake Tswaing thus appears to record the synchronous minimum in summer insolation in the southern hemisphere. 
The similarities between the record of hydrological change from Lake Tswaing and other records of climate change from southern Africa provide some confidence in our interpretation of the sediment archive and point to similar controls on climate in northeastern South Africa, the northern Kalahari and southern Tanzania. On a seasonal scale, these areas receive rainfall during southern hemisphere summer, when the ITCZ reaches its southernmost position and easterly winds bring moisture to the subcontinent form the western Indian Ocean (Fig. 2) (Tyson, 1986; Tyson and Preston-Whyte, 2000). It has been shown that Indian Ocean surface temperatures (IOSTs) varied synchronously with northern hemisphere sea and air temeratures over the last 150 kyr BP (Bard et al., 1997) (Fig. $9 \mathrm{f}, \mathrm{g}$ ), indicating that the changes in climate in southern Africa described above, were not caused directly by higher IOSTs. Stokes et al. (1997) proposed that the sea surface temperature (SST) gradient between the western Indian Ocean and the eastern South Atlantic caused wet/dry phases in the Kalahari, suggesting that the Kalahari (and thus Lake Tswaing) experienced wetter conditions when the SST gradient was low. To test this hypothesis, we calculated the SST gradient between the south-eastern Atlantic and the south-western Indian Ocean over the last $21 \mathrm{kyr}$, using data from Bard et al. (1997) and Kim et al. (2002) (Fig. 10 a). The SST gradient decreases substantially between 18 and $17 \mathrm{kyr} \mathrm{BP}$, just before the records of the intensities of elements related to detrital input increase in the sediments from Tswaing, indicating more humid conditions and supporting the hypothesis that changes in the SST gradient may have affected conditions at Tswaing by determining the inland penetration of tropical easterly air masses. The fact that intensities of detrital elements decrease during the Holocene, when the SST gradient is still low, might be explained by low summer insolation during this period. Modelling studies indicate that present day rainfall over south-eastern Africa is sensitive to changing SSTs in the south-western 
Indian Ocean (Reason, 2002a; Reason, 2002b; Washington and Preston, 2006), but it is not possible to test whether this connection exists on glacial/interglacial time scales, due to a lack of records from the Indian Ocean.

An alternative explanation, which has been proposed based on palaeoclimatic records from a well-dated core from Lake Masoko in southern Tanzania ( $G$ in Fig. 1), is that the ITCZ was displaced southward during the Younger Dryas and the Last Glacial Maximum, increasing precipitation at Lake Masoko $\sim 23-19$ kyr and $\sim 15-11.7$ kyr BP (Garcin et al. 2006a, Garcin et al. 2006b); a phenomenon that has also been described in archives from Central America (Cruz et al., 2005; Haug et al., 2001; Wang et al., 2004) and subtropical Asia (Wang et al., 2001). Modelling results confirm that cold periods in the northern hemisphere that are linked to perturbations in the meridional overturning circulation can induce a southward shift in the position of the ITCZ (Chiang et al., 2003; Zhang and Delworth, 2005). The humid period recorded in Lake Tswaing sediments at 15-10 kyr BP might correspond to the humid phase 15-11.7 kyr BP in the Lake Masoko record and may represent a response to the Younger Dryas in the northern hemisphere, but there is no clear response to earlier millennial-scale cooling events such as Heinrich events known from northern hemisphere climate archives (e.g. Hemming, 2004).

\section{Conclusions}

The study of the organic matter present in the sediments from Lake Tswaing using organic petrology and Rock-Eval pyrolysis, in combination with detailed geochemical analysis of the bulk sediment (TIC, TOC, TN and high-resolution XRF-scanning), provides new insights into changes in this lake system during the last $\sim 200 \mathrm{kyr} B P$. During periods with higher precipitation and increased detrital input from the catchment, lower water column stability, and oxidising conditions at the lake bottom, 
the preservation of autochthonous and allochthonous OM decreased. In contrast, when higher $\mathrm{Cl}$ intensities indicate more saline conditions, allochthonous and autochthonous $\mathrm{OM}$ are well preserved, probably because the lake was stratified for significant periods of time, creating anoxic conditions in the bottom waters. The interpretation of these records in terms of palaeoclimatic change corroborates the findings that precessionally-controlled insolation had an important influence on the hydrological cycle in southern Africa between 200 and 80 kyr BP and the Holocene (Bühmann and Elsenbroek, 1999; Partridge, 1999; Scott, 1999). During the last glacial period, however, processes that are presumably linked to changes in the position of the ITCZ and/or changes in ocean circulation appear to dominate over the influence of insolation, leading to more humid conditions at 73-68 kyr, $54-50 \mathrm{kyr}, 37-$ $35 \mathrm{kyr}$ and $15-10 \mathrm{kyr}$ BP. To better constrain the underlying processes responsible for these changes, the chronology of sediments from Lake Tswaing must be improved and high-resolution records from the surrounding oceans are needed.

\section{Acknowledgements}

We acknowledge the GFZ for funding this work and the coring and Jörg Negendank for the enthusiastic support for this second coring campaign. We further thank Helge Arz, Klaus Zink, Gerald Haug, Brian Horsfield and Maarten de Wit for helpful discussions. Tim Partridge is especially thanked for useful information about the site and the coring as well as for all his support in field trips to and sampling campaigns at Lake Tswaing. We acknowledge Vera Lukies (Bremen) and Rik Tjallingii (now at Kiel University) for technical support and discussion and Dr Stephanie de Villiers and an anonymous reviewer for constructive comments on our manuscript. This is Inkaba yeAfrica contribution 20 . 


\section{References}

Acocks, J. P. H. (1953). Veld types of South Africa. Government Printer, Pretoria, pp. 192.

Ashton, P. J. (1999). Limnology of the Pretoria Saltpan crater lake. In: T. C. Partridge (Editor), Tswaing, investigations into the origin, age and palaeoenvironments of the Pretoria Saltpan. Council of Geoscience (Geological Survey of South Africa), Pretoria, 72-90.

Ashton, P. J., and Schoeman, F. R. (1983). Limnological studies on the Pretoria Salt Pan, a hypersaline maar lake. Hydrobiologia 99, 61-73.

Bard, E., Rostek, F., and Sonzogni, C. (1997). Interhemispheric synchrony of the last deglaciation inferred from alkenone palaeothermometry. Nature 385, 707-710.

Bassinot, F. C., Labeyrie, L. D., Vincent, E., Quidelleur, X., Shackleton, N. J., and Lancelot, Y. (1994). The astronomical theory of climate and the age of the Brunhes-Matuyama magnetic reversal. Earth and Planetary Science Letters 126, 91-108.

Brandt, D., and Reimold, W. U. (1999). The Geology and Geophysical Signature of the Pretoria Saltpan (Tswaing) Impact Structure. In: T. C. Partridge (Editor), Tswaing, investigations into the origin, age and palaeoenvironments of the Pretoria Saltpan. Council of Geoscience (Geological Survey of South Africa), Pretoria, 6-34.

Brook, G. A., Cowart, J. B., Brandt, S. A., and Scott, L. (1997). Quaternary climatic change in southern and eastern Africa during the last $300 \mathrm{ka}$ : the evidence from caves in Somalia and the Transvaal region of South Africa. Zeitschrift für Geomorphologie Supplementband 108, 15-48.

Bühmann, D., and Elsenbroek, J. H. (1999). Mineralogy and geochemistry of the Pretoria Saltpan borehole core. In: T. C. Partridge (Editor), Tswaing, investigations into the origin, age and palaeoenvironments of the Pretoria Saltpan. Council of Geoscience (Geological Survey of South Africa), Pretoria, 91-117.

Butzer, K. W., Fock, G. J., Stuckenrath, R., Zilch, A. (1973). Palaeohydrology of Late Pleistocene Lake, Alexandersfontein, Kimberley, South Africa. Nature 243, 328-330. 
Chiang, J. C. H., Biasutti, M., and Battisti, D. S. (2003). Sensitivity of the Atlantic Intertropical Convergence Zone to Last Glacial Maximum boundary conditions. Paleoceanography 18(4), 1094, doi:10.1029/2003PA000916.

Clemens, S. C., Prell, W. L., Murray, D., Shimmield, G. B., and Weedon, G. (1991). Forcing mechanisms of the Indian Ocean monsoon. Nature 353, 720-725. Cruz, F. W., Jr., Burns, S. J., Karmann, I., Sharp, W. D., Vuille, M., Cardoso, A. O., Ferrari, J. A., Silva Dias, P. L., and Viana, O., Jr. (2005). Insolation-driven changes in atmospheric circulation over the past 116,000 years in subtropical Brazil. Nature 434, 63-66.

deMenocal, P., Ortiz, J., Guilderson, T., Adkins, J., Sarnthein, M., Baker, L., and Yarusinsky, M. (2000). Abrupt onset and termination of the African Humid Period: rapid climate responses to gradual insolation forcing. Quaternary Science Reviews 19, 347-361.

Espitalié, J., Deroo, G., Marquis, F. (1985). La pyrolyse Rock-Eval et ses applications (1ère partie). Revue de l'Institut Francais du Pétrole 40, 563-579.

Espitalié, J., Laporte, J. L., Madec, M., Marquis, F., Leplat, P., Paulet, J., and Boutefeu, A. (1977). Méthode rapide de caractérisation des roches méres, de leur potential pétrolier et de leur degré d'évolution. Revue de l'Institut Francais Pétrole 32, 23-42.

Eugster, H. P., and Hardie, L. A. (1978). Saline Lakes. In A. Lerman (Editor), Lakes: Chemistry, Geology, Physics. Springer-Verlag, New York - Heidelberg - Berlin, pp. 363.

Finney, B. P., Scholz, C. A., Johnson, T. C., and Trumbore, S. (1996). Late Quaternary Lake-level Changes of Lake Malawi. In T. C. Johnson, and E. O. Odada, (Editors), The Limnology, Climatology and Paleoclimatology of the East African Lakes. Gordon and Breach Publishers, Amsterdam, pp. 664.

Fuhrmann, A., Fischer, T., Lücke, A., Brauer, A., Zolitschka, B., Horsfield, B., Negendank, J. F. W., Schleser, G. H., and Wilkes, H. (2004). Late Quaternary environmental and climatic changes in central Europe as inferred from the composition of organic matter in annually laminated maar lake sediments. Geochemistry, Geophysics, Geosystems 5, Q11015.

Fuhrmann, A., Mingram, J., Lücke, A., Houyuan, L., Horsfield, B., Jiaqi, L., Negendank, J. F. W., Schleser, G. H., and Wilkes, H. (2003). Variations in organic matter composition in sediments from Lake Huguang Maar 
(Huguangyan), south China during the last $68 \mathrm{ka}$ : implications for environmental and climatic change. Organic Geochemistry 34, 1497-1515.

Garcin, Y., Vincens, A., Williamson, D., Guiot, J., Buchet, G. (2006a). Wet phases in tropical southern Africa during the last glacial period. Geophysical Research Letters 33(L07703).

Garcin, Y., Williamson, D., Taieb, M., Vincens, A., Mathé, P.-E., Majule, A. (2006b). Centennial to millennial changes in maar-lake deposition during the last 45,000 years in tropical Southern Africa (Lake Masoko, Tanzania). Palaeogeography, Palaeoclimatology, Palaeoecology 239(3-4), 334-354.

Gasse, F. (2000). Hydrological changes in the African tropics since the Last Glacial Maximum. Quaternary Science Reviews 19, 189-211.

Haug, G. H., Hughen, K. A., Sigman, D. M., Peterson, L. C., and Röhl, U. (2001). Southward Migration of the Intertropical Convergence Zone Through the Holocene. Science 293, 1304-1308.

Hemming, S. R. (2004). Heinrich events: Massive late Pleistocene detritus layers of the north Atlantic and their global climate imprint. Review of Geophysics 42, doi:10.1029/2003RG000128.

Holmgren, K., Karlen, W., and Shaw, P. A. (1995). Paleoclimatic Significance of the Stable Isotopic Composition and Petrology of a Late Pleistocene Stalagmite from Botswana. Quaternary Research 43, 320-328.

Holmgren, K., Lee-Thorp, J. A., Cooper, G. R. J., Lundblad, K., Partridge, T. C., Scott, L., Sithaldeen, R., Siep Talma, A., and Tyson, P. D. (2003). Persistent millennial-scale climatic variability over the past 25,000 years in Southern Africa. Quaternary Science Reviews 22, 2311-2326.

Johnson, T. C., Brown, E. T., McManus, J., Barry, S., Barker, P., and Gasse, F. (2002). A High-Resolution Paleoclimate Record Spanning the Past 25,000 Years in Southern East Africa. Science 296, 113-132.

Jourdan, F., Renne, P. R., and Reimold, W. U. (2007). The problem of inherited ${ }^{40} \mathrm{Ar}^{*}$ in dating impact glass by the ${ }^{40} \mathrm{Ar} /{ }^{39} \mathrm{Ar}$ method: Evidence from the Tswaing impact crater (South Africa). Geochimica et Cosmochimica Acta 71, 12141231.

Kim, J.-H., Schneider, R. R., Muller, P. J., and Wefer, G. (2002). Interhemispheric comparison of deglacial sea-surface temperature patterns in Atlantic eastern boundary currents. Earth and Planetary Science Letters 194, 383-393. 
Koeberl, C., Shirey, S. B., and Reimold, W. U. (1999). The origin of the Pretoria Saltpan crater. In: T. C. Partridge (Editor), Tswaing, investigations into the origin, age and palaeoenvironments of the Pretoria Saltpan. Council of Geoscience (Geological Survey of South Africa), Pretoria, 55-63.

Kuper, R., and Kropelin, S. (2006). Climate-Controlled Holocene Occupation in the Sahara: Motor of Africa's Evolution. Science 313, 803-807.

Lafargue, E., Marquis, F., and Pillot, D. (1998). Rock-Eval 6 applications in hydrocarbon exploration, production and soil contamination studies. Revue de I'Institut Francais du Pétrole 53, 421-437.

Lee-Thorp, J. A., Holmgren, K., Lauritzen, S. E., Linge, H., Moberg, A., Partridge, T. C., Stevenson, C., and Tyson, P. D. (2001). Rapid climate shifts in the southern African interior throughout the mid to late Holocene. Geophysical Research Letters 28, 4507-4510.

McCormac, F. G., Hogg, A. G., Blackwell, P. G., Buck, C. E., Higham, T. F. G., and Reimer, P. J. (2004). SHCal04 Southern Hemisphere Calibration 0 - 11.0 cal kyr BP. Radiocarbon 46, 1087-1092.

Metcalfe, S. E. (1999). Diatoms from the Pretoria Saltpan - a record of lake evolution and environmental change. In: T. C. Partridge (Editor), Tswaing, investigations into the origin, age and palaeoenvironments of the Pretoria Saltpan. Council of Geoscience (Geological Survey of South Africa), Pretoria, 172-192.

Meyers, P. A. (2003). Applications of organic geochemistry to paleolimnological reconstructions: a summary of examples from the Laurentian Great Lakes. Organic Geochemistry 34, 261-289.

Meyers, P. A., and Lallier-Vergès, E. (1999). Lacustrine Sedimentary Organic Matter Records of Late Quaternary Paleoclimates. Journal of Paleolimnology 21, 345372.

Munyikwa, K. (2005). Synchrony of Southern Hemisphere Late Pleistocene arid episodes: A review of luminescence chronologies from arid aeolian landscapes south of the Equator. Quaternary Science Reviews 24, 2555-2583.

O'Connor, P. W., and Thomas, D. S. G. (1999). The Timing and Environmental Significance of Late Quaternary Linear Dune Development in Western Zambia. Quaternary Research 52, 44-55.

Partridge, T. C. (1999). The sedimentary record and its implications for rainfall fluctuations in the past. In: T. C. Partridge (Editor), Tswaing, investigations into 
the origin, age and palaeoenvironments of the Pretoria Saltpan. Council of Geoscience (Geological Survey of South Africa), Pretoria, 193-198.

Partridge, T. C. (2002). Were Heinrich events forced from the southern hemisphere? South African Journal of Science 98, 43-46.

Partridge, T. C., DeMenocal, P. B., Lorentz, S. A., Paiker, M. J., and Vogel, J. C. (1997). Orbital forcing of climate over South Africa: a 200,000-year rainfall record from the Pretoria Saltpan. Quaternary Science Reviews 16, 1125-1133. Partridge, T. C., Kerr, S. J., Metcalfe, S. E., Scott, L., Talma, A. S., and Vogel, J. C. (1993). The Pretoria Saltpan: a 200,000 year Southern African lacustrine sequence. Palaeogeography,Palaeoclimatology, Palaeoecology 101, 317 337.

Partridge, T. C., Scott, L., and Hamilton, J. E. (1999). Synthetic reconstructions of southern African environments during the Last Glacial Maximum (21-18 kyr) and the Holocene Altithermal (8-6 kyr). Quaternary International 57/58, 207214.

Patience, A. J., Lallier-Verges, E., Alberic, P., Desprairies, A., and Tribovillard, N. (1996). Relationships between organo-mineral supply and early diagenesis in the lacustrine environment: A study of surficial sediments from the Lac du Bouchet (Haute Loire, France). Quaternary Science Reviews 15, 213.

Pickering, R., Hancox, P. J., Lee-Thorp, J. A., Grün, R., Mortimer, G. E., McCulloch, M. T., and Berger, L. R. (in press). Stratigraphy, U-Th chronology, and paleoenvironments at Gladysvale Cave: insights into the climatic control of South African hominin bearing cave deposits. Journal of Human Evolution.

Powers, L. A., Johnson, T. C., Werne, J. P., and Castaneda, I. S. (2005). Large temperature variability in the southern African tropics since the Last Glacial Maximum. Geophysical Research Letters 32, L08706 1-4.

Prell, W. L., and Campo, E. V. (1986). Coherent response of Arabian Sea upwelling and pollen transport to late Quaternary monsoonal winds. Nature 323, 526528.

Preston-Whyte, R. A., and Tyson, P. D. (1988). The Atmosphere and Weather of Southern Africa. Oxford University Press, Cape Town.

Reason, C. J. C. (2002a). Sensitivity of the southern African circulation to dipole seasurface temperature patterns in the south Indian Ocean. International Journal of Climatology 22, 377-393. 
Reason, C. J. C. (2002b). Subtropical Indian Ocean SST dipole events and southern African rainfall. Geophysical Research Letters 28, 2225-2227.

Reimer, P. J., Baillie, M. G. L., Bard, E., Bayliss, A., Beck, J. W., Bertrand, C., Blackwell, P. G., Buck, C. E., Burr, G., Cutler, K. B., Damon, P. E., Edwards, R. L., Fairbanks, R. G., Friedrich, M., Guilderson, T. P., Hughen, K. A., Kromer, B., McCormac, F. G., Manning, S., Bronk Ramsey, C., Reimer, R. W., Remmele, S., Southon, J. R., Stuiver, M., Talamo, S., Taylor, F. W., J., v. d. P., and Weyhenmeyer, C. E. (2004). INTCAL04 terrestrial radiocarbon age calibration, 0-26 cal kyr BP. Radiocarbon 46, 1029-1058.

Reimold, W. U., Koeberl, C., Partridge, T. C., and Kerr, S. J. (1992). Pretoria Saltpan crater: Impact origin confirmed. Geology 20, 1079-1082.

Richter, T. O., Van der Gast, S., Koster, R., Vaars, A., Gieles, R., De Stigter, H. C., De Haas, H., and Van Weering, T. C. E. (2006). The Avaatech XRF Core Scanner: technical description and applications to NE Atlantic sediments. In: R. G. Rothwell (Editor), New Techniques in Sediments Core Analysis. Geological Society London, Special Publication, London, pp. 39-51.

Röhl, U., and Abrams, L. J. (2000). High-resolution, downhole, and nondestructive core measurements from sites 999 and 1001 in the Caribbean Sea: Application to the late Paleocene Thermal Maximum. In: R. M. Leckie, H. Sigurdsson, G. D. Acton, and G. Draper (Editors), Proceedings of the Ocean Drilling Program, Scientific Results, 191-203.

Scott, L. (1999). Palynological analysis of the Pretoria Saltpan (Tswaing crater) sediments and vegetation history in the Bushveld Savanna biome, South Africa. In: T. C. Partridge (Editor), Tswaing, investigations into the origin, age and palaeoenvironments of the Pretoria Saltpan. Council of Geoscience (Geological Survey of South Africa), Pretoria, 143-166.

Scott, L., and Holmgren, K. (2003). Age interpretation of the Wonderkrater Spring sediments and vegetation change in the Savanna Biome, Limpopo province, South Africa. South African Journal of Science 99, 484-488.

Sifeddine, A., Bertrand, P., Lallier-Verges, E., and Patience, A. J. (1996). Lacustrine organic fluxes and palaeoclimatic variations during the last $15 \mathrm{ka}$ : Lac du bouchet (Massif Central, France). Quaternary Science Reviews 15, 203.

Stokes, S., Haynes, G., Thomas, D. S. G., Horrocks, J. L., Higginson, M., and Malifa, M. (1998). Punctuated aridity in southern Africa during the last glacial cycle: 
The chronology of linear dune construction in the northeastern Kalahari. Palaeogeography, Palaeoclimatology, Palaeoecology 137, 305-322.

Stokes, S., Thomas, D. S. G., and Washington, R. (1997). Multiple episodes of aridity in southern Africa since the last interglacial period. Nature 388, 154.

Talma, A. S., and Vogel, J. C. (1992). Late Quaternary paleotemperatures derived from a speleothem from Cango Caves, Cape Province, South Africa. Quaternary Research 37, 203-213.

Taylor, G. H., Teichmüller, M., Davis, A., Diessel, C. F. K., Littke, R., and Robert, P. (1998). Organic Petrology. Borntraeger, Berlin, pp. 704.

Thomas, D. S. G., Brook, G., Shaw, P., Bateman, M., Haberyan, K., Appleton, C., Nash, D., McLaren, S., and Davies, F. (2003). Late Pleistocene wetting and drying in the NW Kalahari: an integrated study from the Tsodilo Hills, Botswana. Quaternary International 104, 53-67.

Thomas, D. S. G., and Shaw, P. A. (2002). Late Quaternary environmental change in central southern Africa: new data, synthesis, issues and prospects. Quaternary Science Reviews 21, 783 - 797.

Tissot, B. P., Pelet, R., and Ungerer, Ph. (1987). Thermal History of Sedimentary Basins, Maturation Indices, and Kinetics of Oil and Gas Generation. AAPG Bulletin 71, 1445-1466.

Tjallingii, R., Röhl, U., Kölling, M., and Bickert, T. (2007). Influence of the water content on X-ray fluorescence core scanning measurements in soft marine sediments. Geochemistry, Geophysics, Geosystems 8, Q02004, doi:10.1029/2006GC001393.

Tyson, P. D. (1986). Climatic Change and Variability in Southern Africa. Oxford University Press, Oxford, pp. 220.

Tyson, P. D. (1999). Late-Quaternary and Holocene palaeoclimates of southern Africa: A synthesis. South African Journal of Geology 102, 335-349.

Tyson, P. D., and Preston-Whyte, R. A. (2000). The weather and climate of southern Africa. Oxford University Press Southern Africa, Cape Town, pp. 396.

Wang, X., Auler, A. S., Edwards, R. L., Cheng, H., Cristalli, P. S., Smart, P. L., Richards, D. A., and Shen, C.-C. (2004). Wet periods in northeastern Brazil over the past $210 \mathrm{kyr}$ linked to distant climate anomalies. Nature 432, 740743. 
Wang, Y. J., Cheng, H., Edwards, R. L., An, Z. S., Wu, J. Y., Shen, C. C., and Dorale, J. A. (2001). A High-Resolution Absolute-Dated Late Pleistocene Monsoon Record from Hulu Cave, China. Science 294, 2345-2348.

Washington, R., and Preston, A. (2006). Extreme wet years over southern Africa: Role of Indian Ocean sea surface temperatures. Journal of Geophysical Research 111, doi:10.1029/2005JD006724.

Zhang, R., and Delworth, T. L. (2005). Simulated Tropical Response to a Substantial Weakening of the Atlantic Thermohaline Circulation. Journal of Climate 18, 1853-1860. 
Figure captions:

Figure 1: a) Map of southern Africa with locations of: Lake Tswaing ( $T, 25^{\circ} 24^{\prime} 30^{\prime \prime} \mathrm{S}$, 2804'59" E), Wonderkrater (W), Makapansgat (M), Gladysvale Cave (C), Tsodilo Hills, northwestern Kalahari (K), Lake Masoko, Tanzania (G), Lake Malawi (L) and Alexandersfontein (A). Dune and cave studies in northern Namibia, Botswana and Zambia are available from Munyikwa (2005); Thomas and Shaw (2002); O'Connor and Thomas (1999); Stokes et al. (1998); Stokes et al. (1997) (left frame), and further cave studies in south-eastern Africa from Brook et al. (1997) (right frame); b) Crater lake Tswaing with present day vegetation: Acacia dominating the lower slope, Spirostachys and Combretum dominating the upper slope, grasses and reeds (Typha and Cyperaceae) along the shore (T.C. Partridge, pers. comm.) and c) close-up of grasses and sandy shore with dried bacterial lake sediments.

Figure 2: Precipitation and wind vectors for the $925 \mathrm{hPa}$ pressure level (small arrows indicate direction, speed is proportional to arrow length) for Africa in January and August (http://iridl.Ideo.columbia.edu, based on NOAA_NCEP data, satellite estimates and rain gauge data), together with main features of atmospheric circulation: Inter Tropical Convergence Zone (ITCZ), Congo Air Boundary (CAB), the subtropical high over the South Atlantic and influence of the westerlies (big arrow) during winter.

Figure 3: Lithology of the sediments recovered from Lake Tswaing in 2001/2002. 
Figure 4: a) Age/depth plot for the complete profile, based on radiocarbon ages and the assumed start of lacustrine sedimentation at $\sim 200 \mathrm{kyr} \mathrm{BP}$; the basal age is estimated from the impact age of $220 \pm 52$ kyr BP (Koeberl et al., 1999), from tuning (for the time window $50-200 \mathrm{kyr}$ BP the age is tuned to local insolation) and from extrapolation of sedimentation rates (for a detailed description of the age model beyond the limit of radiocarbon dating see also Partridge et al., 1997). Filled circles represent radiocarbon ages of charcoal samples, open circles represent radiocarbon ages of bulk OM samples which were both collected from the 2000/2001 core. The two youngest ages include a reservoir correction of 1,150 yrs (Partridge et al., 1997). The depth scale is corrected for mass flows. The grey area delimits the extent of figure $4 \mathrm{~b}, \mathrm{~b})$ Age/depth plot and sedimentation rates for the upper $20 \mathrm{~m}$ of the Lake Tswaing sediments. The radiocarbon ages of Partridge et al. (1993) are shown in light grey (triangles).

Figure 5: Content (wt \%) of total inorganic carbon (TIC), total organic carbon (TOC), total nitrogen (TN) and the TOC/TN ratio of the sediments from Lake Tswaing. Thick lines are 5-point running averages of the respective fraction. Left column indicates approximate marine oxygen isotope stages according to Bassinot et al. (1994).

Figure 6: Intensities of major elements ( $\mathrm{Si}, \mathrm{K}, \mathrm{Ti}, \mathrm{Fe}, \mathrm{Al}, \mathrm{S}, \mathrm{Ca}$ and $\mathrm{Cl}$ ) from XRF-core scanning of the upper $31 \mathrm{~m}$ of sediments from Lake Tswaing. Thick lines show 7point running averages. The mineralogical composition is redrawn after Bühmann and Elsenbroek (1999). It has been transferred to the new corrected depth scale to facilitate comparison. Abbreviations: halite $(H I)$, smectites $(S m)$, quartz $(Q z)$, plagioclase (Plg), microcline (Mkl). Left column indicates approximate marine oxygen 
isotope stages according to Bassinot et al. (1994). Grey bars highlight humid periods with increased detrital input and reduced precipitation of halite.

Figure 7: a) Laminated sediment from $21.4 \mathrm{~m}$ depth ( 59 kyr BP), Botryococcus braunii colonies (B) and filamentous cyanobacteria or algae $(\mathrm{F})$; b) laminated sediment from $29.5 \mathrm{~m}$ depth ( $80 \mathrm{kyr} \mathrm{BP})$, rich in filamentous cyanobacteria or algae $(F)$, terrestrial material $(T)$ appears dark and is enriched in distinct layers; c) organicpoor sediment sample from $34.8 \mathrm{~m}$ depth ( 92 kyr BP), where only small quantities of highly reflecting terrestrial particles are present; d) highly reflecting terrestrial particle (fusinite) from $29.5 \mathrm{~m}$ depth; e) fresh organic plant material from $21.4 \mathrm{~m}$ depth; f) laminated section (44.7 m depth, $\sim 115 \mathrm{kyr} \mathrm{BP}$ ) with detrital (De), diatom (Di) and carbonate (C) layers (arrow points down). Figure 7 a) and b) show photographs taken under blue light excitation, $7 \mathrm{c}$ ) to e) are taken under reflected white light, $7 \mathrm{f}$ ) shows a thin section photo taken under normal white light.

Figure 8: $\mathrm{HI}-\mathrm{T}_{\max }$ diagram. Sample labels correspond to sample numbers in Tab. 2. For explanation of $\mathrm{HI}$ and $\mathrm{T}_{\max }$ see text, chapter 3; for explanation of the kerogen types I, II, III see text in section 5.3. $\mathrm{R}_{\mathrm{r}}$ indicates reflectance/maturity of the OM (Taylor et al., 1998).

Figure 9: Comparison between a) the total inorganic content (TIC, 5-point running average) of the Lake Tswaing sediments for the last $220 \mathrm{kyr}$ BP (this study; triangles indicate calibrated radiocarbon dates); b) reconstructed rainfall for Lake Tswaing (Partridge, 1999) together with local summer insolation (pale grey curve) at $30^{\circ} \mathrm{S} ; \mathrm{c}$ ) speleothem growth during humid phases in south-east Africa (black) and speleothem growth during more arid phases in presently drowned caves from northern Namibia 
(striped) (Brook et al., 1997); d) dune activity during arid phases in the northern Kalahari (Munyikwa, 2005; O'Connor and Thomas, 1999; Thomas and Shaw, 2002); e) the $\mathrm{Cl}$ (green curve) and $\mathrm{K}$ intensities (red curve) of Lake Tswaing sediments (this study); f) the alkenone-derived sea surface temperature (SST) records from the western Indian Ocean cores MD79257 $\left(20^{\circ} 24^{\prime} \mathrm{S}, 36^{\circ} 20^{\prime} \mathrm{E}\right.$, orange curve) and MD85674 (31' $\mathrm{N}, 50^{\circ} 26^{\prime} \mathrm{E}$, black curve) (Bard et al., 1997). The black and white bar at the top depicts marine oxygen isotope stages (after Bassinot et al. ,1994).

Figure 10: Comparison between a) the calculated difference between Indian (Bard et al., 1997) and south-east Atlantic alkenone-derived SSTs (Kim et al., 2002), b) the Cl intensities from Lake Tswaing sediments, c) the $\delta^{18} \mathrm{O}$ and the d) $\delta^{13} \mathrm{C}$ records from the Makapansgat Valley $\left(24^{\circ} 8.824^{\prime} \mathrm{S}, 2^{\circ} 10.371^{\prime} \mathrm{E}\right)$ (Holmgren et al., 2003), e) the $\mathrm{K}$ intensities from Lake Tswaing sediments, f) the temperature and g) the humidity indices derived from the Wonderkrater pollen record $\left(24^{\circ} 25.806^{\prime} \mathrm{S}, 28^{\circ} 44.626^{\prime} \mathrm{E}\right)$ (Scott and Holmgren, 2003) for the last $25 \mathrm{kyr}$ BP. Triangles indicate calibrated radiocarbon ages.

Table 1: Radiocarbon ages for Lake Tswaing sediments.

Table 2: Hydrogen Index (HI), total organic carbon content (TOC) and $T_{\max }$ values of Lake Tswaing sediments. 

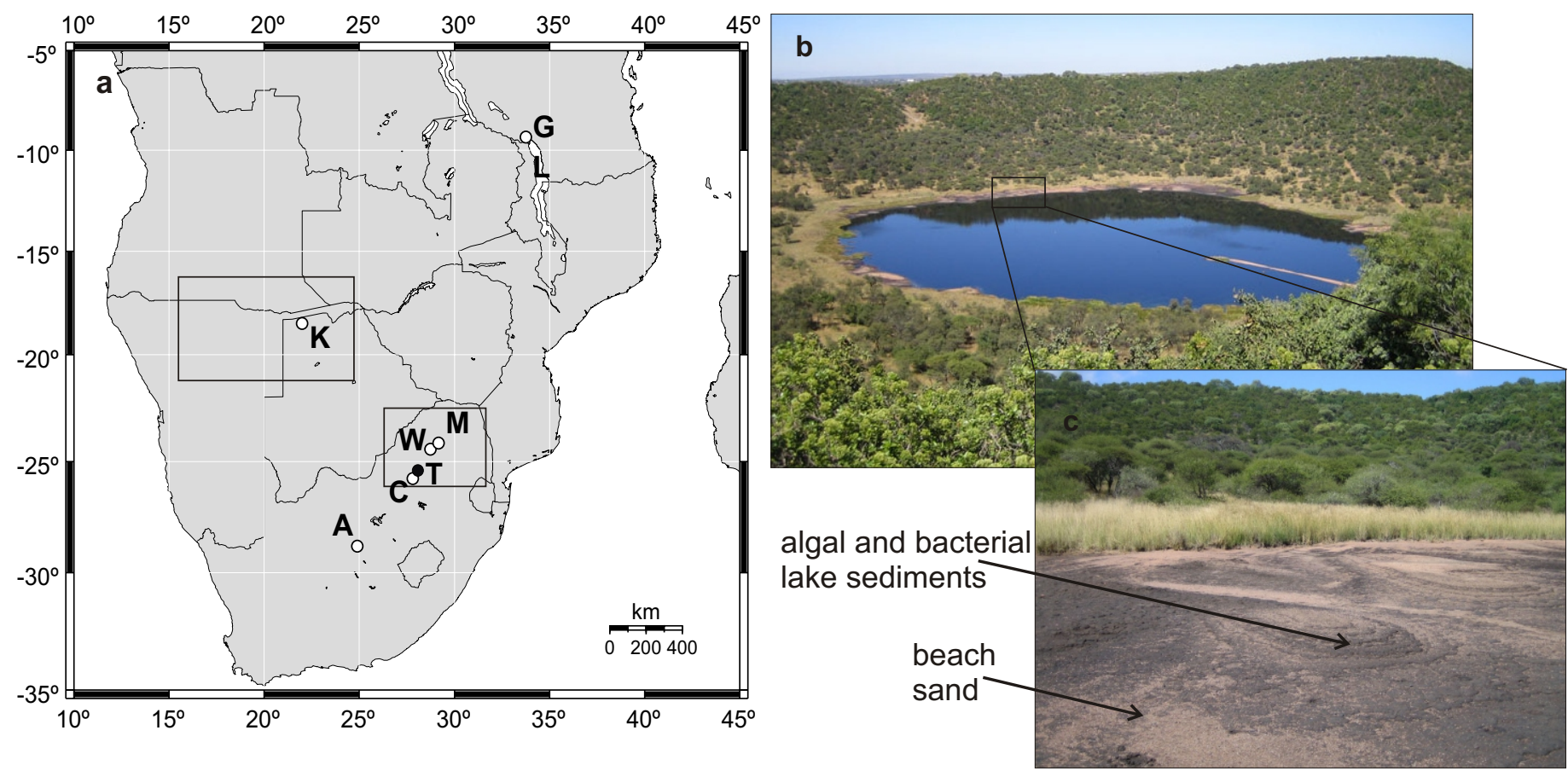


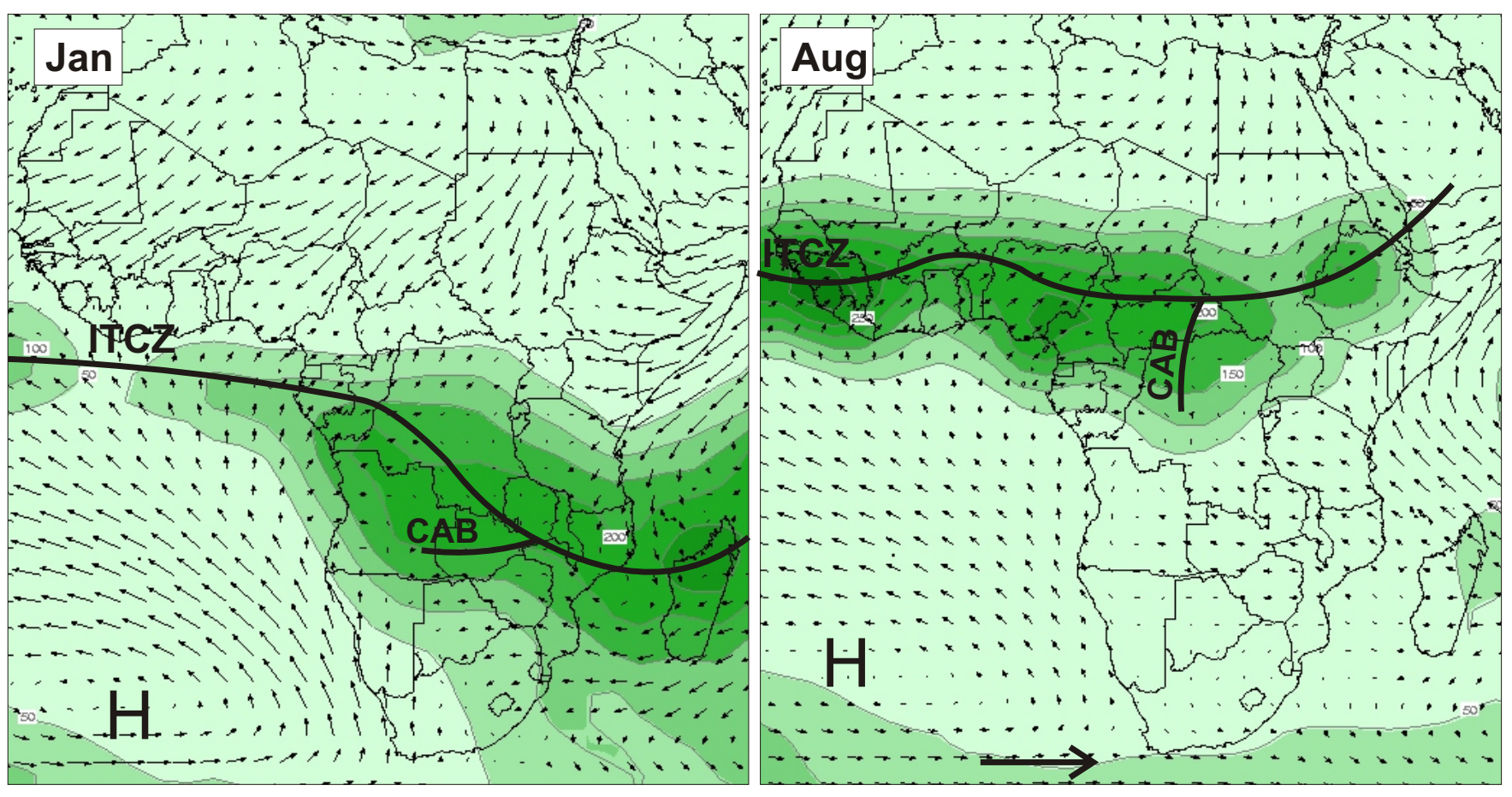

$\begin{array}{llllllllll}50 & 100 & 150 & 200 & 250 & 300 & 350 & 400 & 450 & 500\end{array}$ Precipitation ( $\mathrm{mm} / \mathrm{month})$ 


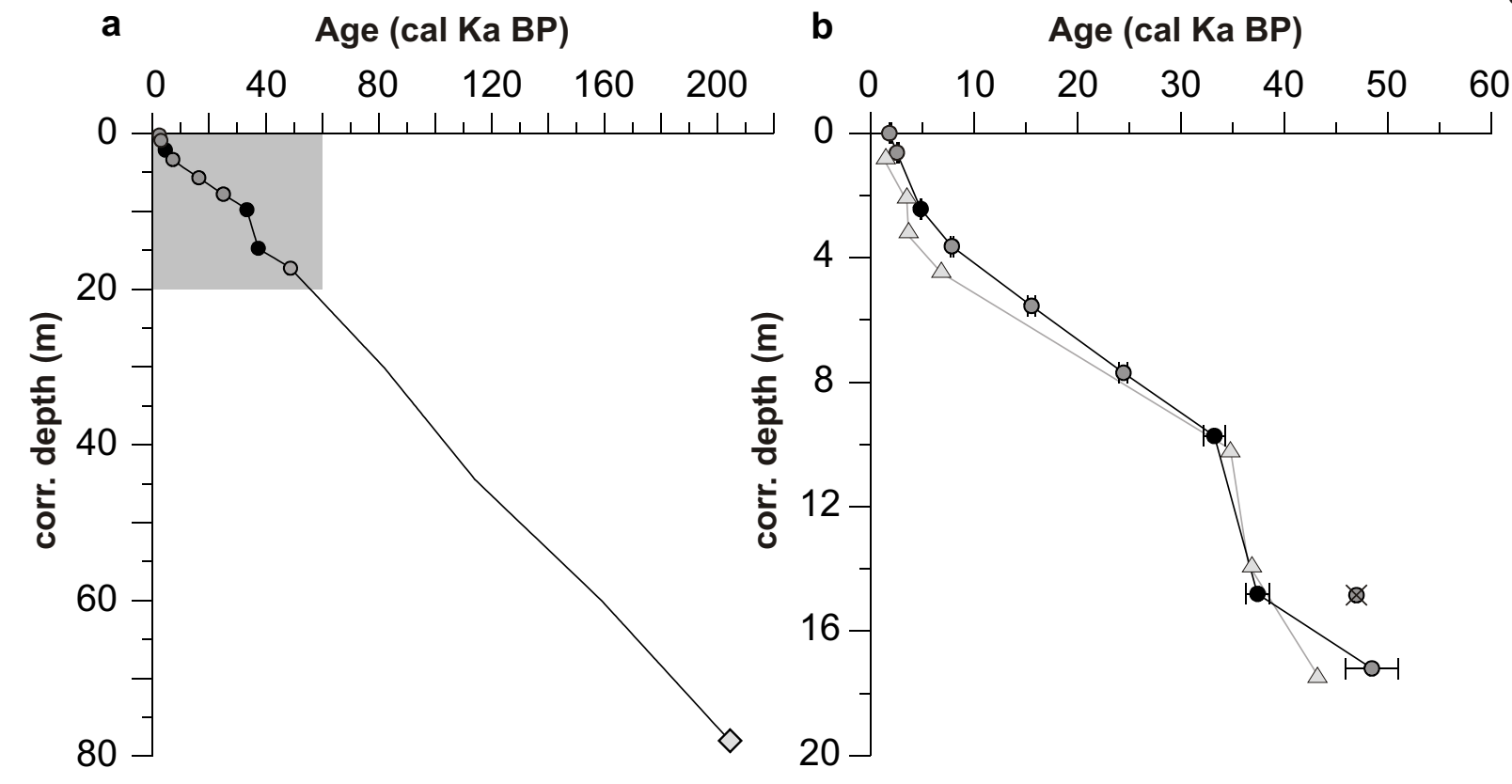

b Age (cal Ka BP)

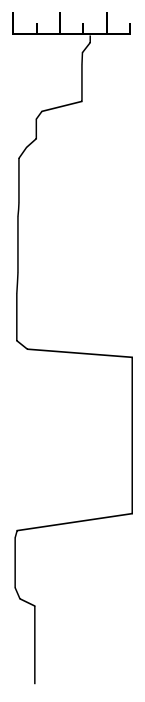


TIC (wt \%)

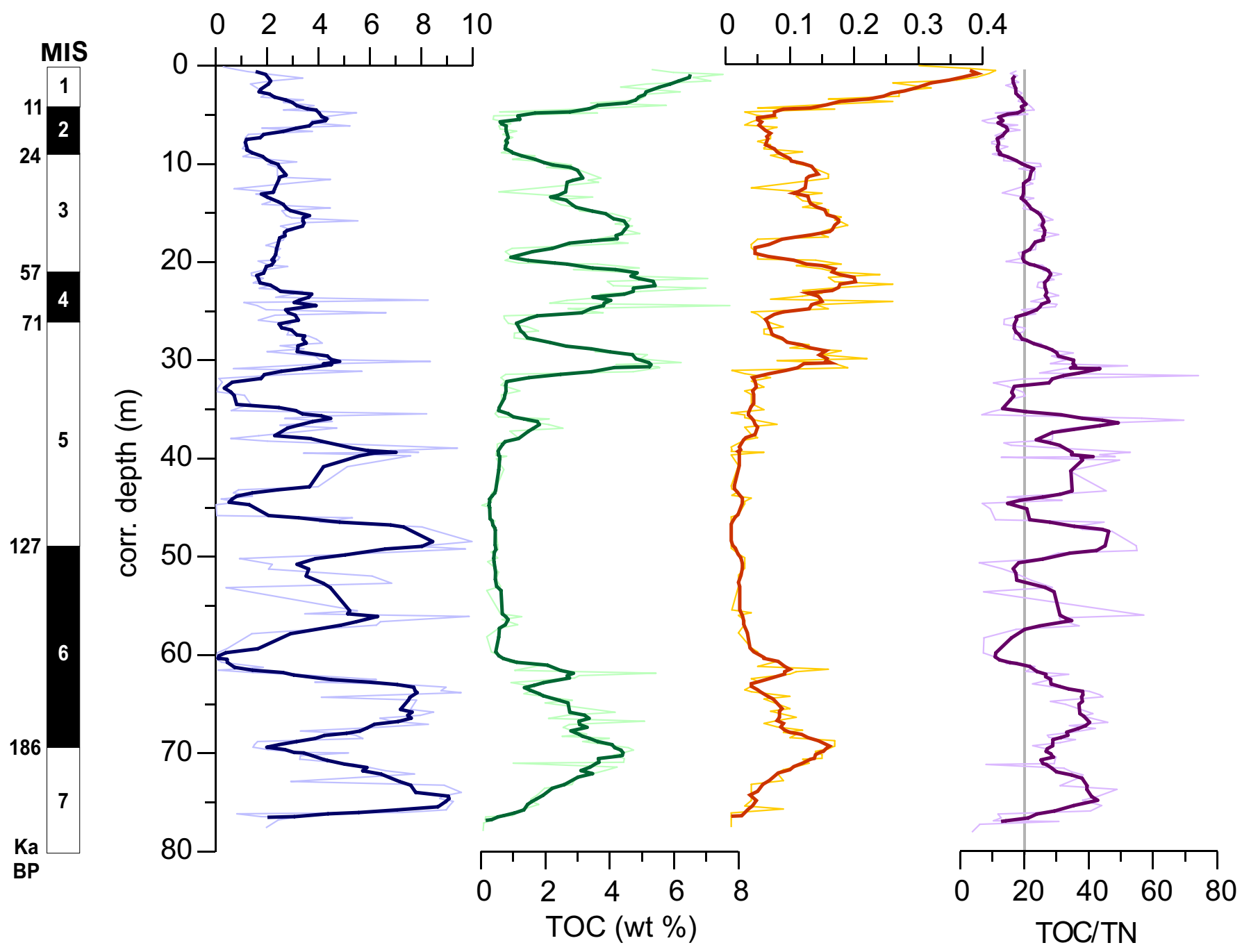




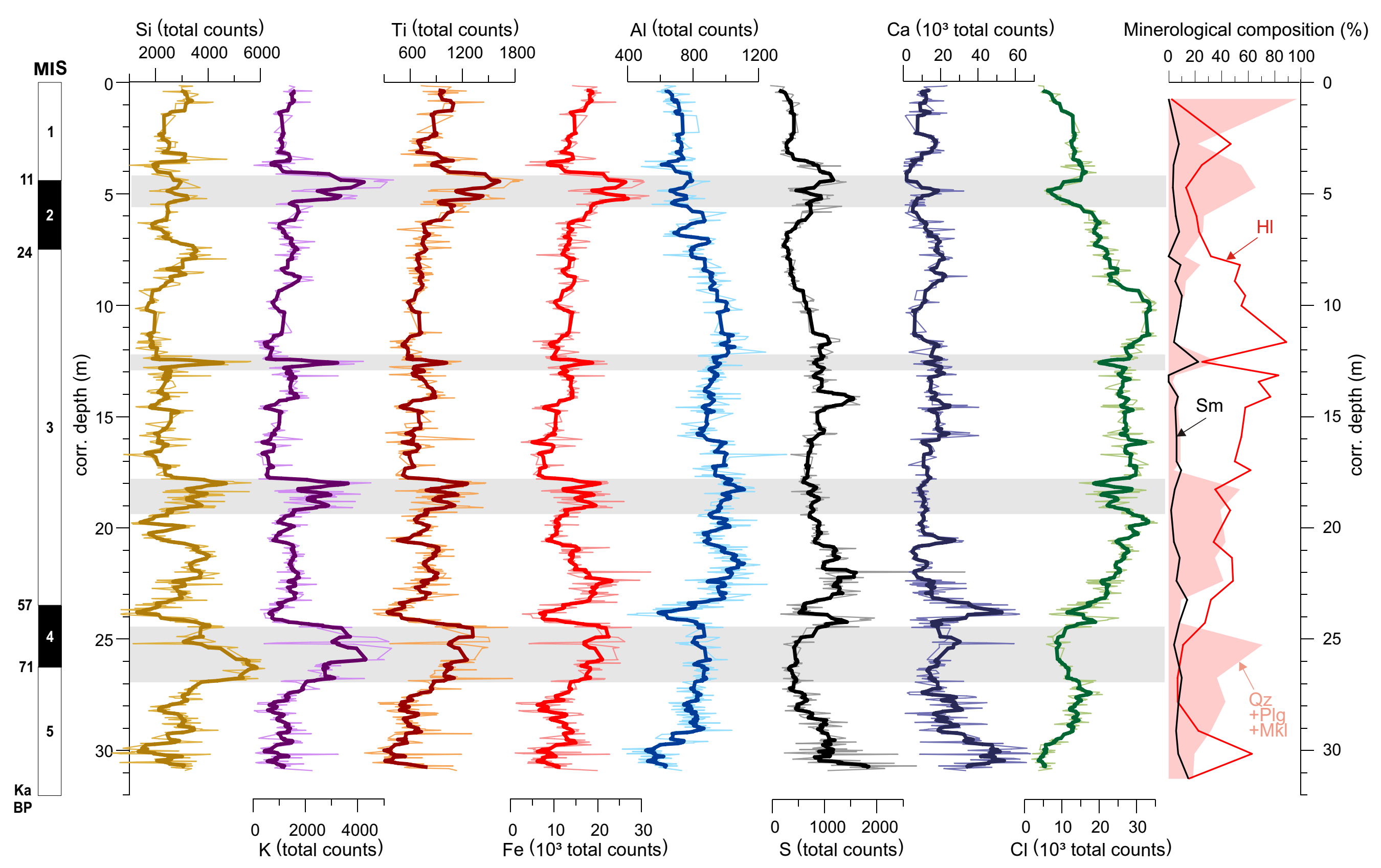



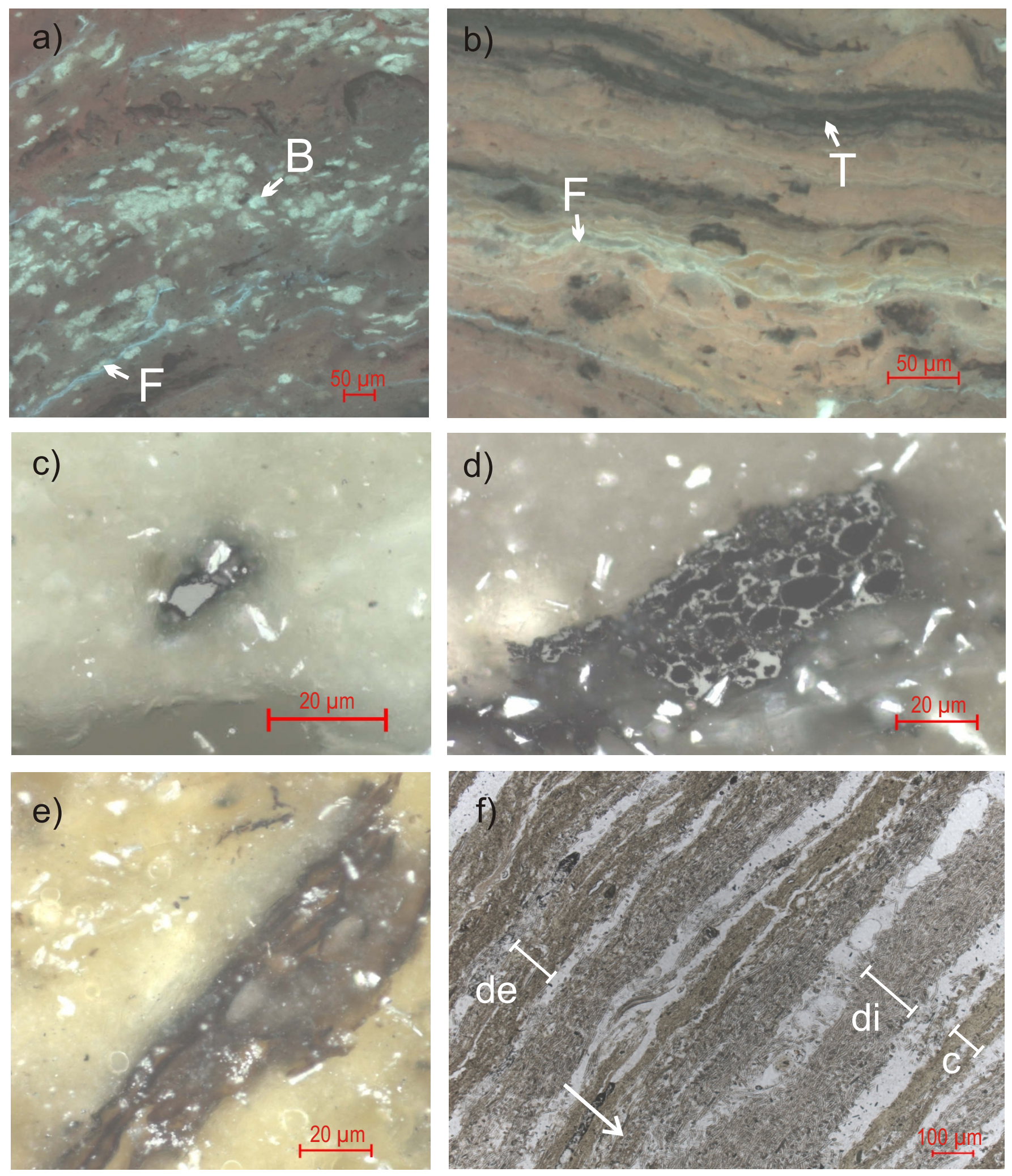

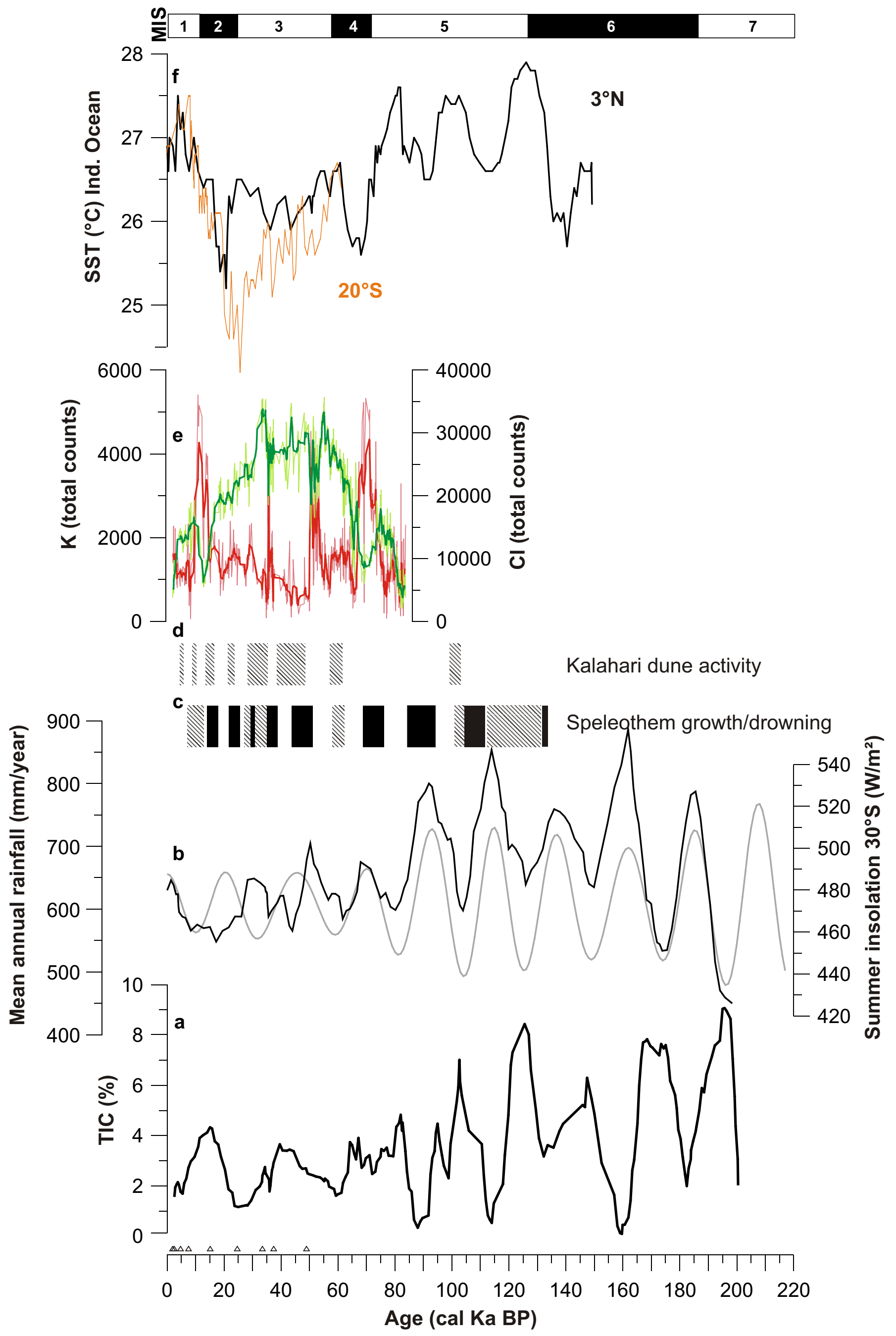


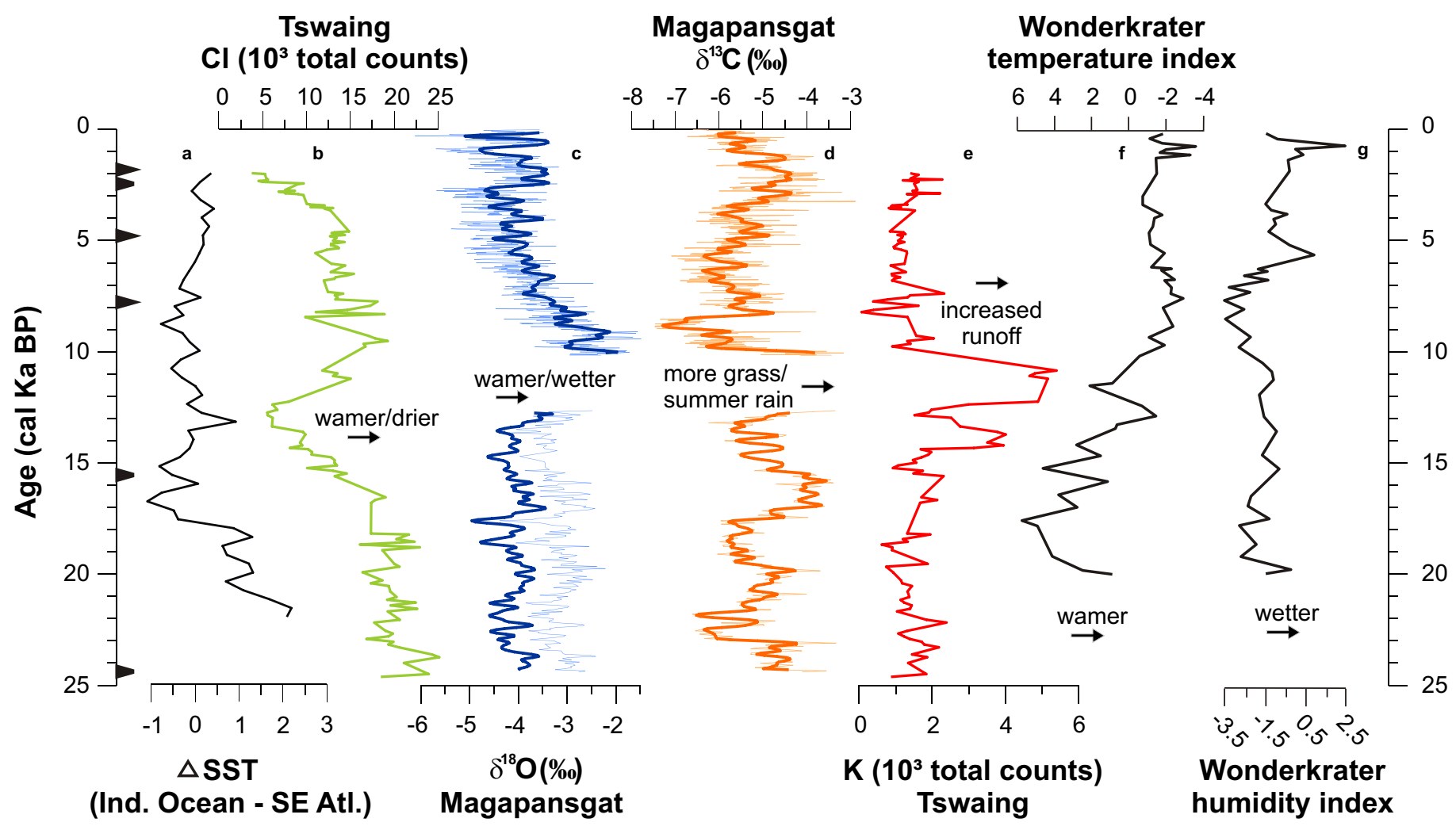


Table 1

\begin{tabular}{|c|c|c|c|c|c|c|}
\hline $\begin{array}{c}\text { original depth } \\
(\mathbf{m})\end{array}$ & $\begin{array}{c}\text { corrected depth } \\
\mathbf{( m )}\end{array}$ & $\begin{array}{c}{ }^{14} \mathbf{C} \text { age } \\
(\mathbf{y r} \mathbf{B P})\end{array}$ & Std. dev. \pm & $\begin{array}{c}\text { calibrated age } \\
(\mathbf{y r} \mathbf{B P})\end{array}$ & $\pm 2 \sigma$ & material \\
\hline $1.595-1.605$ & 0 & 3095 & 35 & $1810^{\star}$ & 91 & TOC \\
\hline $2.21-2.24$ & $0.61-0.64$ & 3675 & 35 & $2538^{\star}$ & 175 & TOC \\
\hline $4.005-4.065$ & $2.405-2.465$ & 4305 & 30 & $4837^{\star}$ & 35 & charcoal \\
\hline $5.23-5.24$ & $3.63-3.64$ & 7090 & 50 & $7850^{\star}$ & 115 & TOC \\
\hline $7.36-7.38$ & $5.54-5.56$ & 13130 & 70 & $15550^{\star}$ & 356 & TOC \\
\hline $9.785-9.795$ & $7.695-7.705$ & 20410 & 130 & $24440^{\star}$ & 405 & TOC \\
\hline $11.835-11.885$ & $9.705-9.755$ & 28500 & 600 & $33220^{\star \star}$ & 1072 & charcoal \\
\hline $16.990-17.020$ & $14.790-14.820$ & 31900 & 800 & $37390^{\star \star}$ & 1120 & charcoal \\
\hline $19.385-19.395$ & $17.195-17.205$ & 44800 & 2100 & $48440^{\star \star}$ & 2559 & TOC \\
\hline
\end{tabular}

${ }^{*}$ Calib 5.0.2 after McCormac et al. (2004) and Reimer et al. (2004)

${ }^{\star *}$ CalPal (calibration curve CalPal2005_SFCP) 
Table 2

\begin{tabular}{|c|c|c|c|c|}
\hline Sample & $\begin{array}{c}\text { corr. } \\
\text { depth } \\
(\mathbf{m})\end{array}$ & $\begin{array}{c}\text { TOC } \\
(\mathbf{w t} \%)\end{array}$ & $\begin{array}{c}\mathbf{T}_{\max } \\
\left({ }^{\circ} \mathbf{C}\right)\end{array}$ & $\begin{array}{c}\mathbf{H I} \mathbf{~ ( m g ~} \\
\mathbf{H C l}\end{array}$ \\
\hline 1 & 0.6 & 6.13 & 426.0 & 412.0 \\
\hline 2 & 7.5 & 0.44 & 428.0 & 177.0 \\
\hline 4 & 11.1 & 2.32 & 427.0 & 320.0 \\
\hline 5 & 12.5 & 0.27 & 422.0 & 136.0 \\
\hline 6 & 16.3 & 3.29 & 434.0 & 372.0 \\
\hline 7 & 19.2 & 0.31 & 427.0 & 95.0 \\
\hline 8 & 21.4 & 6.32 & 431.0 & 495.0 \\
\hline 9 & 25.2 & 0.71 & 440.0 & 114.0 \\
\hline 10 & 25.4 & 0.31 & 430.0 & 111.0 \\
\hline 11 & 29.5 & 4.92 & 429.0 & 470.0 \\
\hline 12 & 34.8 & 0.34 & 357.5 & 75.0 \\
\hline 13 & 36.6 & 1.36 & 449.5 & 542.0 \\
\hline 14 & 39.2 & 0.37 & 325.0 & 114.5 \\
\hline 15 & 44.7 & 0.19 & 315.0 & 226.0 \\
\hline 16 & 48.4 & 0.19 & 373.0 & 47.5 \\
\hline 17 & 60.1 & 0.52 & 426.0 & 116.0 \\
\hline 18 & 61.5 & 4.77 & 433.5 & 522.0 \\
\hline 19 & 63.3 & 0.77 & 435.5 & 172.5 \\
\hline 20 & 68.8 & 3.32 & 434.0 & 389.5 \\
\hline 21 & 69.4 & 4.68 & 433.5 & 410.0 \\
\hline 22 & 74.9 & 1.31 & 433.5 & 502.5 \\
\hline & & & & \\
\hline
\end{tabular}

